\title{
Contribution of Breast Volume and Weight to Body Fat Distribution in Females
}

\author{
VICTOR L. KATCH, BARBARA CAMPAIGNE, PATTY FREEDSON, \\ STANLEY SADY, FRANK I. KATCH, ALBERT R. BEHNKE \\ Research Laboratories, Physical Education Department, The University of \\ Michigan, Ann Arbor, Michigan 48109 (V.L.K., B.C., P.F., S.S.), and \\ Department of Exercise Science, University of Massachusetts, Amherst, \\ Massachusetts 01035 (F.I.K., A.R.B.)
}

\begin{abstract}
KEY WORDS Breast volume, Breast weight, Percent fat, Body weight, Sex-specific fat, Body composition, Body fat, Fat distribution
\end{abstract}

\begin{abstract}
Breast volume and body composition were measured in 45 adult females to determine the contribution of breast weight and breast volume to total body fat. Plaster casts were filled with sand of known density to obtain breast volume. Breast weight was computed as breast volume times its density. The correlation between total breast volume and percent body fat was $r=.40$. Breast weight ( $\overline{\mathrm{X}}=484$ grams) accounted for 3.5 percent of the total weight of body fat, and at most, 12 percent of the estimated quantities of sex-specific fat. A theoretical model is proposed for the distribution of body fat in the female which subdivides total body fat into three components: reserve storage fat, essential fat, and expendable storage fat.
\end{abstract}

For the purposes of in vitro and in vivo analysis and evaluation, the human body is sometimes viewed comprising two major components, lean body mass and fat weight, each with its own density. If the whole body density $\left(D_{b}\right)$ is known (consisting of two intermixed but known densities), it is possible to calculate the relative and absolute fat and lean components, respectively (Brozek et al., '63). Behnke ('69) has suggested that the body's total quantity of fat can be partitioned into two compartments. One major subdivision is termed storage fat, representative of nutritional status located in subcutaneous depots and comprised of lipid triglyceride. For males and females storage fat averages about 8 to 10 percent of total body weight. The second compartment, essential fat, contributes 2 to 4 percent of body weight in the male and approximately 14 percent in the female. Essential fat is located in bone marrow, the deep fat stores, intramuscularly, and throughout the central nervous system. Essential fat in the female also includes sex-specific fat, believed located in mammary and other tissues (Behnke and Wilmore, '74). The quantity of sex-specific fat is thought to range from 8 to 12 percent, although there are no direct quantitative estimates.
Support for the above compositional model of the body fat stores comes from several sources. Parizkova's ('63) data on newborns showed larger skinfold levels in females, particularly at the iliac region. This difference was maintained during postnatal weight loss and persisted throughout childhood into adulthood. Additional data from other studies (Kornfeld and Schuller, '30; Merselis and Texler, '25; Shafrir and Wertheimer, '65; Garn, '53; and Boynton '36) have confirmed quantitative sex differences in body fat.

It seems self-evident that mammary tissue fat constitutes a large sex-specific fat depot in the female. It is common opinion among surgeons and pathologists that the mammary tissue is essentially a fatty organ (Geschichter, '45; Witten, '71). In an autopsy study of 800 women, Sandison ('62) reported that the breasts of young women (age range 21-45 years) appeared to be an irregular cone of fibrous tissue covered by a "fatty envelope." In older women (age range 51-70 years) the breast appeared to undergo involution, becoming atropic and remaining fibrous with or without fatty infiltration. While Sandison reported

Received March 6, 1979; accepted October 25, 1979. 
no quantitative data, it was his opinion, and one apparently shared by others (Ingleby, '49), that the breast contains "large," but differing amounts of fat, depending on age and nutritional status.

No data are available concerning the contribution of breast volume and weight to total body volume, body weight, or body fat. In the present study an analysis is made of the contribution of the breast to total body fat in the female. A model for the distribution of body fat is also presented with special references to the contribution of mammary tissue.

\section{METHODS}

Forty-five University and non-University females (age range 18-31 years) were recruited from advertisements in local newspapers. All respondents were Caucasian and were judged free from disease based on a medical questionnaire and interview. Informed consent was obtained in accordance with established Use of Human Subjects Procedures.

Body weight was measured to the nearest 50 grams using a beam balance scale, with subjects clothed in a two-piece nylon swim suit. Height was measured with a conventional stadiometer to the nearest $0.5 \mathrm{~cm}$.

Total body volume (TBV) was measured by hydrostatic weighing in the seated position. A minimum of eight to 10 trials was performed, with the average of the last three trials used as the underwater weight score (Katch et al. '67). Duplicate residual lung volume (RLV) measures were made in a bent-forward seated position by the oxygen dilution technique (Wilmore, '69). The mean of the two trials was used in all calculations. Test-retest reliability for 60 subjects was $r=.92$, with a standard error of measurement of $\pm 79 \mathrm{ml}$.

Percent body fat was calculated from body density by use of the Siri ('61) equation ( $\%$ fat $=$ $495 / \mathrm{D}_{\mathrm{b}}-450$ ) and lean body weight was obtained by subtraction.

Breast volume was measured in the upright standing position by application of fast setting plaster bandages (Johnson \& Johnson \#1). Vaseline was applied to the breast region to prevent adhesion of the plaster to the skin. The bandages were applied from below the clavicle to above the umbilicus and extending laterally to the midaxillary line. The cast dried in three to five minutes and was removed with little discomfort. Cast volumes were determined by filling with sand of known density $(1.435 \mathrm{~g}$ $\mathrm{ml}^{-1}$ ) to a level approximating the curvature of the chest wall. The weight of the sand was de- termined by weighing to the nearest 0.01 grams using a Ohaus Triple Beam Balance Scale. Each cast was lined with 1-ply of cellophane to prevent distortion and adhesion. Cast volume was calculated as cast weight times sand density. The right and left breast volume for each cast was measured separately and added to compute total breast volume. Details of the method have been published elsewhere (Campaigne et al., '79). Test-retest reliability was $r=.97$.

Duplicate measurements for five skinfolds were secured by the same investigator by use of a Lange caliper. Test-retest reliability was no lower than $r=0.92$ for any of the sites measured. The mean of the duplicate trials was used in all analyses. The skinfolds included: subscapula-inferior angle of the scapula with the fold running parallel to the axillary border; triceps-midway between the acromion and olecranon process on the posterior aspect of the arm, the arm held vertically with the fold running parallel to the length of the arm; abdomen-horizontal fold adjacent to the umbilicus; iliac-vertical fold on the crest of the ilium at the midaxillary line; thigh-vertical fold on the anterior aspect of the thigh midway between the hip and knee joints.

The following girths were measured in duplicate with a cloth tape and Gullick handle: chest-maximum girth of the thorax at the level of the axilla, including material of the unpadded top of a two-piece bathing suit at mid tidal volume; $a b d o m e n$ - laterally at the level of the iliac crest and anteriorly at the umbilicus; hips-anteriorly at the level of the symphysis pubis and posteriorly at maximal protrusion of the gluteal muscles over the bathing suit; thigh-just below the gluteal fold, or maximal thigh girth. Test-retest reliability for each of the girth measurements was $r=0.90$ or higher. The cloth tape was periodically checked for calibration; no stretching occurred during testing.

To investigate the extent to which differences in body size and fat relate to differences in breast volume, subjects were stratified into three percentile groups $(0-33$ percentile; $33-66$ percentile; and 66-100 percentile). These groups were designated Low Fat (mean percent fat $=17.4 \%, \mathrm{~N}=12$ ), Medium Fat (mean percent fat $=23.6 \%, \mathrm{~N}=22$ ), High Fat (mean percent fat $=30.4 \%, \mathrm{~N}=11$ ). The mean percent fat for the total group closely approximates the mean fat level for this age group, as reported in numerous studies (see review by Katch and McArdle, '75). 


\section{RESULTS AND DISCUSSION}

Table 1 presents the descriptive data and ANOVA for the three subgroups of all variables. There were no statistical differences for lean body weight, breast volume and chest girth between the groups. Several of the other girths and skinfolds resulted in statistical differences. As expected, there were significant differences between the groups for percent fat, fat weight, and body density.

It was our initial expectation that fatter subjects would possess larger breast volumes, but this was not true. While the mean differences were in the expected direction, apparently, the large variability caused the non-significant differences between the three groups.

Table 2 lists the correlations between breast volume and the body composition, skinfold, and circumference variables. The highest correlation with breast volume is chest girth, $r=0.73$, $(\mathrm{p}<.05)$. The relationship between total breast volume and body volume $(r=0.44)$, body weight $(r=0.42)$, and lean body weight $(r=$ 0.20 ) indicates only low to moderate association. This further points to the large variability in breast volume for subjects who differ widely in body composition. While many of the correlations listed in Table 2 are statistically significant, the magnitude of the coefficients of determination $\left(r^{2} \times 100\right)$ indicates only poor to moderate stability of individual differences.

Table 3 presents the mean $\pm \mathrm{SD}$ for breast weight expressed as a percent of total body fat weight ((breast weight / total body fat weight) $\times 100$ ). For these calculations it was necessary to estimate the density of the breasts (Weight = Density $\times$ Volume). We are unable to locate data on the density of the breast, nor information on quantities or proportions of lipid and non-lipid material in mammary tissue. Therefore, we have chosen a density value for breast tissue of $1.017 \mathrm{~g} \cdot \mathrm{ml}^{-1}$ for use in subsequent calculations.' As can be observed, breast weight accounts for no more than 4.4 percent of total body fat weight. During preliminary testing we observed only two cases that deviated from this trend. For these subjects who were 23.5 and 26.0 percent fat, their breast volume of 1549 and $1427 \mathrm{ml}$ constituted 10.3 and 7.4 percent, respectively, of their total body fat weight. This is quite unusual and deviates dramatically from all of the other subjects tested. We are confident these data are accurate and only serve to illustrate an example of extreme breast development present in a small percent of the population.
The influence of breast volume and breast weight on calculations of percent body fat is shown in Table 4. In this analysis percent fat was computed after breast volume and weight estimates were subtracted from body density. In each case the mean difference is small and non-significant. This illustrates that the net contribution of the breasts to hydrostatically determine percent body fat is really very minimal for women who differ widely in body composition.

Table 5 presents 8,10 , and 12 percent estimates of sex-specific fat weight and total breast weight expressed as a percent of these estimates. At best, breast volume contributes no more than 12.5 percent to sex-specific fat weight. We interpret this to mean there must be other substantial sex-specific fat depots in the female which contribute quantitatively to female body fat stores. Garn ('53) suggests that a fatty envelope covers the entire female body, while others pinpoint the pelvic region as one of the major female sex-specific fat depots (Vague and Fenasse, '65).

Figure 1 illustrates our proposal for body fat distribution in a reference female of $56.7 \mathrm{~kg}$. This "model" shows reserve storage fat clearly distinguished from the essential fat depot. Total body fat comprises 24 percent of the body weight. Our 5 percent estimate for reserve storage fat and 4 percent for essential fat is based partially on empirical data (Shafrir and Wertheimer, '65; Pitts, '62; Alexander, '64), but without firm verification. Allen et al. ('56), for example, have estimated that one-third of the total fat is located subcutaneously, which may be distributed between expendable and reserve storage fat. Johnson et al. ('72) have estimated intramuscular fat at about 10 percent of the body's total fat stores. Alexander's data ('64),

\footnotetext{
${ }^{1}$ Because there are no published data on total breast density we estimated the density as follows: Assume the density of breast fat $\left(D_{t}\right)$ is $0.90 \mathrm{~g} \mathrm{ml}^{-1}$, the density of the non-fat material $\left(D_{1}\right)$ is $1.050 \mathrm{~g} \mathrm{ml}^{-1}$ (this is probably somewhat of a low estimate), and the volume of the breast is $475 \mathrm{ml}$ (the mean in the present study); if we assign the breast 20 percent fat and 80 percent non-fat, the density of the whole breast is: $V_{\mathrm{t}}=W_{\mathrm{f}} / D_{\mathrm{f}}+W_{1} / D$

$V_{(}(475 \mathrm{ml})=\left(.20 W_{\mathrm{f}} / .90\right)+\left(.80 W_{\mathrm{l}} / 1.050\right)$

Solving for $W_{\mathrm{t}}\left(W_{\mathrm{f}}+W_{\mathrm{t}}\right)$

$W_{\mathrm{t}}=475 /\left(.20 / .90 \mathrm{~g} \mathrm{ml}^{-1}\right)+\left(.80 / 1.050 \mathrm{~g} \mathrm{ml}^{-1}\right)$

$W_{\mathrm{t}}=483 \mathrm{~g}$

Where, $W$ represents weight (total breast weight $W_{1}$, breast fat weight $W_{\mathrm{f}}$, and lean breast weight $W_{1}$, and $V_{1}$ is the total breast volume. Of course, the assumption of 20 percent fat weight for the breast is only an estimate. If we use a 10 percent value the density is $1.034 \mathrm{~g} \mathrm{ml}^{-1}$, and 0.971 if we use a 50 percent fat estimate.

Now,

Density $=W, / V$

Density $=483 \mathrm{~g} / 475 \mathrm{~m}$

Density $=1.017 \mathrm{~g} \mathrm{ml}^{-1}$
} 


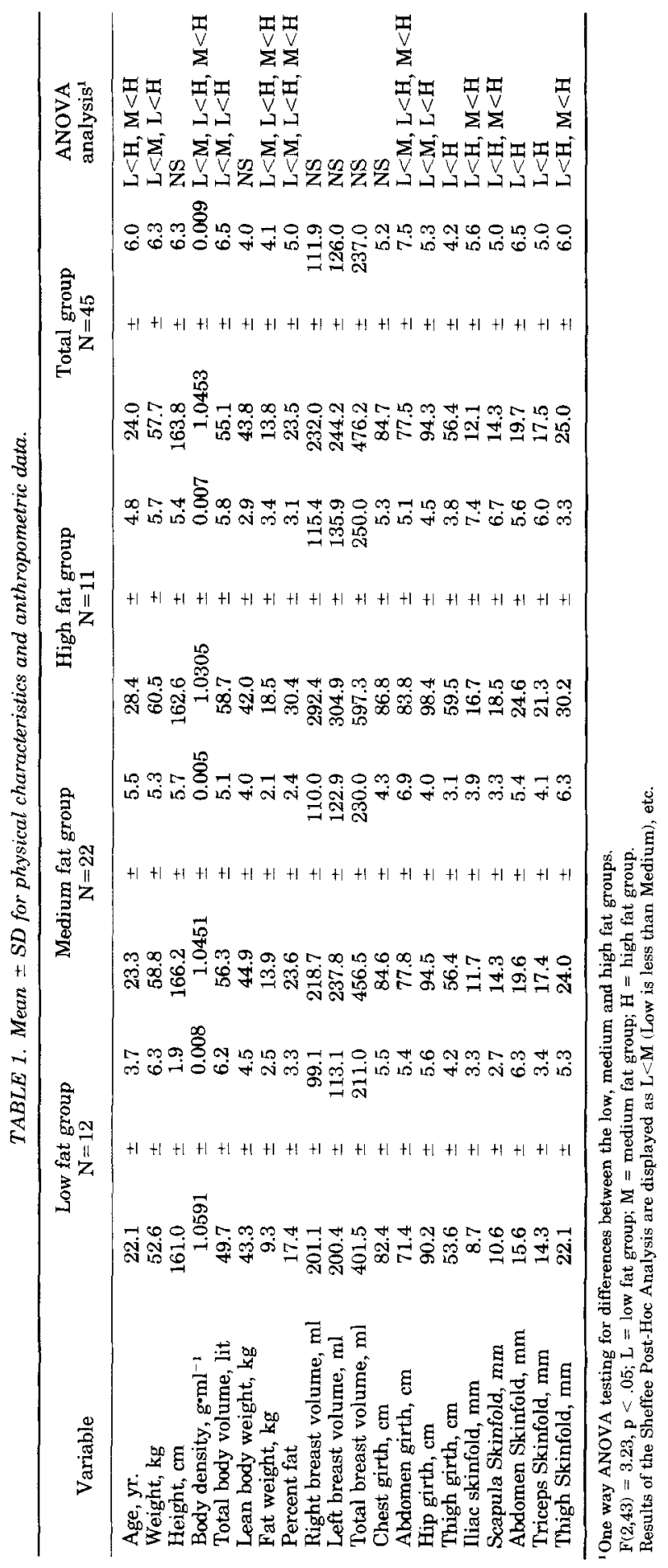


TABLE 2. Correlations between total breast volume and other variables.

\begin{tabular}{|c|c|c|c|c|}
\hline & & Total breast volume & & \\
\hline Variable & $\begin{array}{l}\text { Low fat } \\
\text { group } \\
N=12\end{array}$ & $\begin{array}{l}\text { Medium fat } \\
\text { group }^{2} \\
N=22\end{array}$ & $\begin{array}{l}\text { High fat } \\
\text { group }^{3} \\
\mathrm{~N}=11\end{array}$ & $\begin{array}{l}\text { Total } \\
\text { group } \\
N=45\end{array}$ \\
\hline Body weight & .57 & .34 & .22 & .42 \\
\hline Body density & -.43 & -.32 & -.19 & -.41 \\
\hline Total body volume & .53 & .35 & .24 & .44 \\
\hline Lean body weight & .49 & .22 & .20 & .20 \\
\hline Fat weight & .55 & .43 & .22 & .45 \\
\hline Percent fat & .42 & .32 & .19 & .40 \\
\hline Iliac skinfold & .29 & .39 & .74 & .56 \\
\hline Scapula skinfold & .20 & .26 & .26 & .36 \\
\hline Abdomen skinfold & .45 & .41 & .18 & .45 \\
\hline Triceps skinfold & .34 & -.09 & -.01 & .17 \\
\hline Thigh skinfold & .41 & .09 & -.11 & .26 \\
\hline Chest girth & .73 & .73 & .67 & .73 \\
\hline Abdomen girth & .47 & .26 & .69 & .48 \\
\hline Hip girth & .42 & .39 & .21 & .44 \\
\hline Thigh girth & .31 & .30 & .10 & .35 \\
\hline
\end{tabular}

$1 r \geq .58, \mathrm{p}<.05$

${ }^{2} r \geq .42, \mathrm{p}<.05$

${ }^{3} r \geq 60, \mathrm{p}<.05$

${ }^{4} r \geq .33, \mathrm{p}<.05$

TABLE 3. Mean $\pm S D$ for breast weight and the percentage contribution to total body fat.

\begin{tabular}{lcc}
\hline \multicolumn{1}{c}{ Group' } & $\begin{array}{c}\text { Total breast weight, } \\
\text { grams }\end{array}$ & $\begin{array}{c}\text { Breast weight as a percent } \\
\text { of total body fat }\end{array}$ \\
\hline Low fat group $\mathrm{N}=12$ & $408.3 \pm 201$ & 4.4 \\
Medium fat group $\mathrm{N}=22$ & $464.3 \pm 218$ & 3.3 \\
High fat group $\mathrm{N}=11$ & $607.5 \pm 238$ & 3.3 \\
Total sample $\mathrm{N}=45$ & $484.3 \pm 219$ & 3.5 \\
\hline
\end{tabular}

* A breast density of $1.017 \mathrm{~g} \mathrm{ml}^{-1}$ was used.

'ANOVA analysis showed no significant differences between groups for breast weight or breast weight expressed as a percent of total body fat.

TABLE 4. The contribution of total breast weight and volume to percent body fat in females $(N=45) *$

\begin{tabular}{|c|c|c|c|c|}
\hline Group & $\begin{array}{c}\text { Percent body } \\
\text { fat }\end{array}$ & $\begin{array}{l}\text { Percent body fat with } \\
\text { breast volume and } \\
\text { weight removed }\end{array}$ & $\Delta$ & $\begin{array}{l}\text { Paired } t \text { - } \\
\text { ratio }\end{array}$ \\
\hline $\begin{array}{l}\text { Low fat } \\
\mathrm{N}=12\end{array}$ & $17.4 \pm 3.3$ & $17.2 \pm 3.3$ & -.20 & $\begin{array}{l}0.20 \\
\text { NS }\end{array}$ \\
\hline $\begin{array}{l}\text { Medium fat } \\
\qquad \mathrm{N}=22\end{array}$ & $23.6 \pm 2.4$ & $23.5 \pm 2.4$ & +.10 & $\begin{array}{c}0.10 \\
\text { NS }\end{array}$ \\
\hline $\begin{array}{l}\text { High fat } \\
\quad \mathrm{N}=11\end{array}$ & $30.4 \pm 3.1$ & $30.2 \pm 3.1$ & -.20 & $\begin{array}{l}1.99 \\
\mathrm{NS}\end{array}$ \\
\hline $\begin{array}{l}\text { Total sample } \\
\qquad N=45\end{array}$ & $23.6 \pm 5.0$ & $23.4 \pm 5.0$ & -.20 & $\begin{array}{l}0.20 \\
\mathrm{NS}\end{array}$ \\
\hline
\end{tabular}

* Values are mean $\pm \mathrm{SD}$. 
TABLE 5. Total body weight, sex-specific fat, breast weight, and percent of sex-specific fat located in the breasts.

\begin{tabular}{|c|c|c|c|c|}
\hline Group & Body weight & $\begin{array}{c}\text { Sex-specific } \\
\text { fat weight, kg1 }\end{array}$ & $\begin{array}{l}\text { Breast weight, } \\
\text { kg }\end{array}$ & $\begin{array}{l}\text { Breast weight as } \\
\text { a percent of } \\
\text { sex-specific fat }\end{array}$ \\
\hline $\begin{array}{l}\text { Low fat } \\
\mathbf{N}=12\end{array}$ & 52.6 & $\begin{array}{l}4.21 \\
5.26 \\
6.31\end{array}$ & .408 & $\begin{array}{l}9.7 \\
7.8 \\
6.5\end{array}$ \\
\hline $\begin{array}{l}\text { Medium fat } \\
\quad N=22\end{array}$ & 58.8 & $\begin{array}{l}4.70 \\
5.88 \\
7.06\end{array}$ & .464 & $\begin{array}{l}9.9 \\
7.9 \\
6.0\end{array}$ \\
\hline $\begin{array}{l}\text { High fat } \\
\qquad \mathrm{N}=11\end{array}$ & 60.5 & $\begin{array}{l}4.84 \\
6.05 \\
7.26\end{array}$ & .607 & $\begin{array}{r}12.5 \\
10.0 \\
8.4\end{array}$ \\
\hline $\begin{array}{l}\text { Total sample } \\
\qquad \mathrm{N}=45\end{array}$ & 57.7 & $\begin{array}{l}4.62 \\
5.77 \\
6.92\end{array}$ & .484 & $\begin{array}{r}10.5 \\
8.4 \\
7.0\end{array}$ \\
\hline
\end{tabular}

${ }^{1}$ Sex-specific fat obtained by computing 8,10 , and 12 percent of body weight. These values appear in descending order.

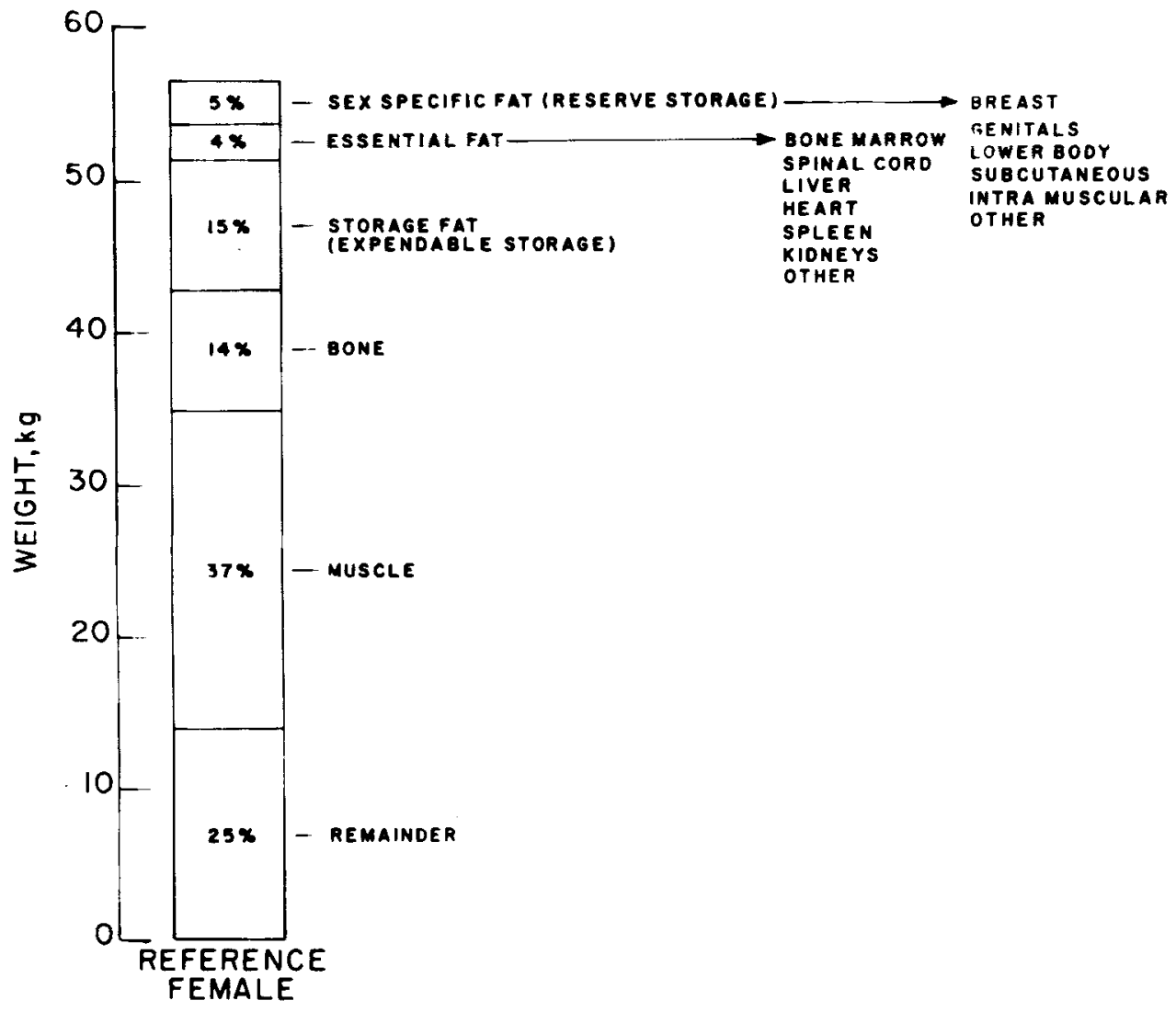

Fig. 1. Proposed Katch-model of body fat distribution in a 56.7 kilogram female, height $=163.8 \mathrm{~cm}$. 
derived from the dissection of the internal abdominal and thoracic fat in 11 males and nine females (estimated from their Figure 2), suggests that about 12 percent of the total adipose tissue is located "internally." Forbes and Amirhakimi (70) and Durnin and Wormersley ('74) have come to similar estimates.

Behnke ('69) has previously introduced the concept of minimal weight in females, which is equivalent to lean body weight in males that includes 2-4 percent essential fat: In the male, minimal weight and lean body weight are identical. For both males and females minimal weight is associated with the leanest individual for a given stature in the population. Minimal weight is calculated from perimetric size (diameters) and stature. The extent to which minimal weight exceeds the lean body weight reflects the sex-specific fat depot. We believe sex-specific fat should be more appropriately termed "reserve storage fat," as small portions may be labile, especially during starvation, while the remainder is non-labile "sex-characteristic" fat. Body fat measurements on extremely lean, athletic females (Brown and Wilmore, 74), including some anorexia nervosa patients (unpublished data, The University of Michigan, '79), reveal values of body fat in the range of 7 to 13 percent, but never, in our experience, lower than 7 to 8 percent, giving validity to the above model.

For the data in Figure 1 the minimal weight for the $56.7 \mathrm{~kg}$ reference female (height $=163.8$ $\mathrm{cm}$ ) would be $48.2 \mathrm{~kg}$ ( 56.7 minus $8.51 \mathrm{~kg}$ storage fat). In this case essential plus reserve storage fat would comprise 10.6 percent of this minimal weight; muscle 43.5 percent; bone 16.5 percent, and the remainder 29.4 percent. These data are similar to the estimates derived by Behnke ('69) and serve to illustrate the differences between expendable, reserve, and storage fat in the female.

Although it is well known that the average fat content of the non-athletic, sedentary female is usually one and one-half to two-fold higher than her male counterpart, the differences in type, location, and function of the additional fat stores are little understood. It would seem reasonable to attribute some genetic or unique biological importance to this increased adiposity, perhaps related to preparation for childbirth and lactation.

\section{ACKNOWLEDGMENTS}

These data are part of Project BIGBLORTS partially funded through NIH Bio-Medical Science Support Grant (V. Katch, Principal Investigator), and the Weight Watchers Foundation (F. Katch, Principal Investigator).

\section{LITERATURE CITED}

Alexander, M.L. (1964) The postmortem estimation of total body fat, muscle and bone. Clinical Science, 26:193-202.

Allen, T.H., M.T. Peug, K.B. Chan, T.F. Huang, C. Chang, and H.S. Fang (1956) Prediction of total adiposity from skinfolds and the curvilinear relationship between external and internal adiposity. Metabolism, 5:346-353.

Behnke, A.R. (1969) New concepts of height-weight relationships. In: Obesity. N.L. Wilson (ed). F.A. Davis Co., Philadelphia, pp. 25-53.

Behnke, A., and J. Wilmore (1974) Evaluation and Regulation of Body Build and Composition, New Jersey, Prentice Hall, Inc.

Boynton, B. (1936) The physical growth of girls: A study of the rhythm of physical growth from anthropometric measurements on girls between birth and eighteen years. University of Towa Studies Child Welfare, 12:1-105.

Brown, H., and J. Wilmore (1974) Physiological profiles of women distance runners. Medicine and Science in Sports. 6:178-181.

Densitometric analysis of body composition: Revisions of some quantitative assumptions. Annals of the New York Academy of Sciences, 110 Part 1:113-140.

Campaigne, B.N., V.L. Katch, F.I. Katch, P. Freedson, and S. Sady (1979) Measurement of breast volume in females: Description of a reliable method. Annals of Human Biology. 6:363-367.

Durnin, J.V.G.A., and J. Womersley (1974) Body fat assessed from total body density and its estimation from skinfold thickness: measurements on 481 men and women aged 16 to 72 years. British Journal of Nutrition, 32:77-97.

Forbes, G.B., and G.H. Amirhakimi (1970) Skinfold thickness and body fat in children. Human Biology, 42:401418.

Garn, S.M. (1953) Fat weight and fat placement in the female. Science, 56:1091.

Geschichter, C.F. (1945) Diseases of the Breast, J.B. Lippincott Co.

Ingleby, H. (1949) Changes in breast volume in a group of normal young females. Bulletin of the International Association of Medical Museums, 29:87-92

Johnson, E.R., R.M. Butterfield, and W.T. Pryor (1972) Studies of fat distribution in the bovine carcass 1 . The partition of fatty tissues between depots. Australian Journal of Agricultural Research, 23:381-388.

Katch, F.I., and W.D. McArdle (1975) Validity of body composition prediction equations for college men and women. American Journal Clinical Nutrition, 28:105-109.

Katch, F.I., E. Michael, and S.M. Horvath (1967) Estimation of body volume by underwater weighing. Description of a simple method. Journal of Applied Physiology, 23:811813.

Kornfeld, W., and H. Schuller (1930) Uber Durckshnittswerte und Bewentungsgnundlager einiger weichterlmasse bei Kindern verschiedener Altersstifen. Zeitschrift fur Kinderheilkonde, 51:349-362. 
Merselis, J.G., and K. Texler (1925) Uber die Fettgewebsverteilung an der Korperoberglache. Zeitschrift fur Konstitutionslchre, 11:576-638.

Parizkova, J. (1963) Impact of age, diet and exercise on man's body composition. Annals of the New York Academy of Science, 110:661-674.

Pitts, G.C. (1962) Density and composition of the lean body compartment and its relationship to fatness. American Journal of Physiology, 202:445-452.

Sandison, A.T. (1962) An autopsy study of the adult human breast. National Cancer Institute Monograph Number 8 , U.S. Department of Health, Education and Welfare.

Shafrir, E., and E. Wertheimer (1965) Comparative physiology of adipose tissue in different sites and in different species. Handbook of Physiology, 5:Adipose Tissue, American Physiological Society, Washington, D.C.

Siri, W.E. (1961) Body composition from fluid spaces and density: analysis of methods. In: Techniques for Measuring body Composition. pp. 223-244. National Academy Sciences-National Research Council, Washington, D.C.

Vague, J., and R. Fenasse (1965) Comparative anatomy of adipose tissue. Handbook of Physiology, 5: Adipose Tissue, American Physiological Society, Washington, D.C.

Wilmore, J.H. (1969) A simplified method for the determination of residual lung volumes. Journal of Applied Physiology, 27:96-100.

Witten, D.M. (1971) The Breast: An Atlas of Tumor Radiology, Yearbook Medical Publishers Inc. 